\title{
Stage-specific mortality of Calanus finmarchicus, Pseudocalanus elongatus and Oithona similis on Fladen Ground, North Sea, during a spring bloom
}

\author{
Ketil Eiane $^{1, *}$, Mark D. Ohman ${ }^{2}$ \\ ${ }^{1}$ University Courses on Svalbard, PO Box 156, 9171 Longyearbyen, Norway \\ ${ }^{2}$ Integrative Oceanography Division, Scripps Institution of Oceanography, University of California San Diego, La Jolla, \\ California 92093-0218, USA
}

\begin{abstract}
We used Woods Population Surface Method to estimate stage-specific mortality rates for populations of Calanus finmarchicus, Pseudocalanus elongatus, and Oithona similis from abundance data obtained during the Fladen Ground Experiment (FLEX 1976) in the northern North Sea. Temperatures from the day and night depth distributions of each developmental stage were used to force temperature functions for the duration of developmental stages. In addition, we considered the influence of potential food-limitation of development, which had only minor effects on the mortality estimates. We show that the risk of mortality changes substantially over the life span of the animals, with notable differences among species. O. similis, in particular, shows negligible losses after naupliar stages 1 and 2, which may account for its numerical dominance in many ocean regions. Differences among taxa are poorly explained by allometry alone and are instead related to species- and stagespecific differences in behavior. The vertical migration behavior of late developmental stages of C. finmarchicus (i.e. their choice of habitat) might help to reduce mortality risk.
\end{abstract}

KEY WORDS: Mortality $\cdot$ Zooplankton · Copepoda $\cdot$ North Sea $\cdot$ Life history $\cdot$ Vertical migration

\section{INTRODUCTION}

The dynamics of zooplankton populations are of special interest for several reasons. Many of the dominant zooplankton species are mostly herbivorous, and therefore constitute much of the secondary production upon which higher trophic levels depend. Insight into the vital rates of natural zooplankton populations is therefore necessary to understand the factors controlling production in pelagic ecosystems. However, much more attention (and considerably more precision) has been focused on the processes of recruitment to populations than on other vital rates of population dynamics (Ohman \& Wood 1995, Ohman \& Hirche 2001). For instance, numerical models often implement very sophisticated considerations of zooplankton grazing, growth, development, and fecundity, but (much to the dissatisfaction of the authors of these studies) are left with very simple assumptions about loss terms (e.g. Carlotti \& Radach 1996, Carlotti et al. 2000).

During the last decade, the risk of mortality has been established as vital for the understanding of habitat choice (Rosland \& Giske 1994, Kaartvedt et al. 1996, Eiane et al. 1997), behavior (Ohman 1990, Fiksen \& Giske 1995, Ohman \& Wood 1995, De Robertis 2002), and life history (Aksnes \& Giske 1990, Kiørboe \& Sabatini 1994, Verity \& Smetacek 1996) of organisms inhabiting the marine pelagial. Without proper estimates of mortality it is very hard, or impossible, to address any of these problems in quantitative terms.

The Fladen Ground Experiment (FLEX 1976) has contributed greatly to our understanding of the spring development of temperate-boreal zooplankton assemblages. This study sought to understand spring bloom dynamics in the northern North Sea, in a region where the influence of horizontal advection is relatively small. 
Some of the important topics that have been addressed include spring succession of the plankton community (Krause \& Radach 1980, Williams \& Lindley 1980a), temporal activity and feeding patterns of zooplankton (Daro 1980, Fransz \& van Arkel 1980), horizontal distribution of zooplankton biomass (Solow \& Steele 1995), habitat choice and patterns of vertical migrations (Krause \& Trahms 1982, Krause \& Radach 1989), and aspects of zooplankton population dynamics (Lindley \& Williams 1980, Williams \& Lindley 1980b, Krause \& Trahms 1983). Reliable techniques for estimating zooplankton mortality rates were not available to these authors; hence, it has not been possible to include quantitative considerations about mortality until now.

In this study we revisit the intensive time series data generated during FLEX 1976 in order to estimate stage-specific mortality rates of 3 species of copepods: Calanus finmarchicus (Gunnerus 1765), Pseudocalanus elongatus (Boeck 1865) and Oithona similis Claus 1866. The selection of copepod species represents a variety of evolutionary solutions to life in the pelagial (Table 1). Mortality has been hypothesized to be lower for the egg-brooding $P$. elongatus and $O$. similis than that of the free-spawning $C$. finmarchicus (Kiørboe \& Sabatini 1994). Furthermore, the small size and reduced swimming activity of the cyclopoid $O$. similis have been assumed to result in lower encounter rates and susceptibility to predators, compared to calanoids (Paffenhöfer 1993).

\section{MATERIALS AND METHODS}

Our analysis is based on the time series data of Calanus finmarchicus, Pseudocalanus elongatus and Oithona similis obtained during the Fladen Ground Experiment in 1976 (FLEX 1976). Data were collected

Table 1. Some of the differences between the species of zooplankton considered in this study as suggested by Paffenhöfer (1993), Kiørboe \& Sabatini (1994), and others. Susp.: suspension

\begin{tabular}{|c|c|c|c|}
\hline Characteristic & C. finmarchicus & P. elongatus & O. similis \\
\hline Order & Calanoida & Calanoida & Cyclopoida \\
\hline Spawning mode & Broadcast & Brooder & Brooder \\
\hline Relative size & Large & Intermediate & Small \\
\hline Relative fecundity & High & Low & Low \\
\hline \multicolumn{3}{|l|}{ Relative mortality } & Low \\
\hline Diet & Herbivore & Herbivore & Omnivore/Carnivore \\
\hline Feeding mode & Susp. feeding & Susp. feeding & Particulate feeding \\
\hline Feeding current & Yes & Yes & No \\
\hline Feeding rate & High & High & Low \\
\hline \multirow[t]{2}{*}{ Swimming mode } & Constantly & Constantly & Drifting \\
\hline & Swimming & Swimming & \\
\hline
\end{tabular}

from RV 'Meteor' at the central station of the FLEX grid $\left(58^{\circ} 55^{\prime} \mathrm{N}, 00^{\circ} 32^{\prime} \mathrm{E}\right)$, and were kindly made available to us by M. Krause. Temperature data were measured by conductivity temperature depth (CTD) sampling every 6 h (Soetje \& Huber 1980; a detailed account on the thermal structure at the central station during FLEX 1976 may be found there). Chl a concentrations were estimated in situ down to 80 or $100 \mathrm{~m}$ depth using a submersible fluorometer (Elektro Optic Suarez, Krause \& Trahms 1982).

Zooplankton sampling was conducted from 26 March to 6 June (Days 85 to 157 of year) with 101 Niskin water bottles 4 times a day (when possible) at standard depths $(3,10,20,30,40,50,60,75$ or 80 , $100 \mathrm{~m}$; on 9 May sampling was also conducted near $150 \mathrm{~m}$ ). Samples were filtered onto $30 \mathrm{~mm}$ gauze and preserved in $4 \%$ buffered formaldehyde. All organisms in each sample were counted and identified to species and, for the dominant species, to developmental stage. Thus, there was no subsampling error. Furthermore, although water bottle samples might reflect small-scale patchiness in the ocean, vertically integrated values from 4 profiles per day were averaged here, serving to considerably reduce the effects of small-scale variability. Krause \& Trahms (1983) give a detailed account of zooplankton sampling at the central station during FLEX 1976.

We computed diel vertical migration (DVM) patterns from copepodid depth distributions by day and night from the part of the data set where the full water column was sampled to $150 \mathrm{~m}$ (10 May to 6 June). There were too few deep vertical profiles available between 10 and 16 May. Averaging the data to 6 June extends slightly beyond the temporal window of our calculations of mortality, but only from 17 May to 6 June, a relatively brief period of time.

We digitized naupliar data from published figures (Krause \& Trahms 1983). Zooplankton abundance data were integrated over depth and pooled into daily averages.

The FLEX 1976 data set contains high quality data on other species. However, due to the lack of knowledge on their developmental times, we did not include them in our analysis. Several other taxa present in the FLEX data set were not included due to low abundance.

Although we expected water bottles to be appropriate sampling devices for nauplii, young copepodids, and adults of the smaller species, we were uncertain about a possible sampling bias against adults of Calanus finmarchicus. However, the results of Rey (2000) sug- 
gest that Niskin bottles quantitatively capture even adult Calanus. At the end of her mesoscosm experiments, Rey (2000) first sampled the mesocosms with Niskin bottles at 5 depths and then drained the mesocosms and counted the actual number of copepods present in each. In comparisons with Calanus spp. copepodid stage 5 (C5), adult males, and adult females, the median ratio of Niskin bottle estimates to the true number of individuals present was 1.28 (range: 1.07 to $1.69, \mathrm{~N}=6$ ). Notably, in all comparisons the ratio was never less than 1 and there was no tendency for C $5 \mathrm{~s}$ to be caught better by the water bottles than the adults. To test for a bias in mortality estimates for the larger developmental stages of $C$. finmarchicus, we used the vertical life table method (Aksnes \& Ohman 1996). This compares mortality rates estimated from the stage frequency data, obtained from undulated Gulf III tows along south to north transect in the FLEX grid at 4 distinct periods (Solow \& Steele 1995), with estimates obtained from water bottle samples for the same periods from the central station. Mortality estimates from these 2 data sources were very similar, and only in one case (C4, May 29 to 1 June) was there a significant (95\% level) difference between estimates. We therefore see no evidence for a sampling bias against adults by this sampling method, provided animals are sufficiently abundant to be captured by bottles, and present our results accordingly.

Mortality rates were estimated using the population surface method (PSM) (Wood 1994). This method makes use of the McKendric-von Foerster equation to fit abundance data for an age-structured population to a smooth surface over age and time (see Wood 1994 for a thorough discussion of the technique). It requires ages of stage classes of individuals to be estimated independently of the abundance data set. We have based our estimates of age within a developmental stage on the observation that copepod developmental rates are strongly affected by temperature (Corkett \& McLaren 1978, Corkett et al. 1986) and, to a lesser extent, by food availability (Vidal 1980, Campbell et al. 2001). Thus, temperature at the weighted mean depth of each developmental stage was used to estimate ages. We explore departures from this assumption below.

Duration of developmental stages of copepods can be approximated by the Bêlehràdek temperature function (Corkett \& McLaren 1978):

$$
D=a(T-\alpha)^{-b}
$$

where $D$ is development time (d), $T$ is ambient temperature and $\mathrm{a}, \alpha$ and $b$ are empirically fitted constants. For most copepods, $b$ can be assumed to be 2.05 and $\alpha$ to be constant throughout the life span (Corkett \& McLaren 1978); a must be fitted for each developmental stage. For Calanus finmarchicus, we used the parameter values from Campbell et al. (2001). For the 2 remaining species, we parameterized Eq. (1) in the following way: For Pseudocalanus elongatus, we utilized Landry's (1983) developmental times for Pseudocalanus sp. (which was probably $P$. newmani) from nauplii stage 1 (N1) to adults (at $15^{\circ} \mathrm{C}$ ). For embryonic durations, we used the experimental results of McLaren et al. (1989) and thereby estimated an embryonic development time of $1.93 \mathrm{~d}$ at $15^{\circ} \mathrm{C}$. Then we computed the ratio between the duration time of each stage as measured by Landry (1983) and the embryonic developmental times from McLaren et al. (1989). The ratios were then converted to a values for use in Eq. (1). For Oithona similis, (1) experimentally obtained durations for developmental stage N1 to adult at $15^{\circ} \mathrm{C}$ (Sabatini \& Kiørboe 1994; their Fig. 7a), (2) $\alpha=-5$, and (3) $a=1430$ for egg duration calculated by Eaton (1971) for embryonic development were used to solve a linearized version of Eq. 1 for values of $a$ at each stage. Temperature functions and parameters $(a, \alpha$ and $b)$ are given in Table 2.

The weighted mean depth of each developmental stage (N1 through adult) of all species was computed, as well as the depth interval within which $80 \%$ of each stage was found. This enabled us to describe the temperature experienced by each stage through time by mapping the depth distributions of animals onto the temperature profiles from the central station (Soetje \& Huber 1980). In doing so, we used the information on day and night distribution (i.e. the DVM pattern) in the data set to account for migrations through the ther-

Table 2. Bêlehràdek temperature functions and parameter values $(a, \alpha$ and $b)$ from the literature or computed from data given in the literature for each copepod species. Dev.: developmental. See 'Materials and methods' for details

\begin{tabular}{|c|c|c|c|}
\hline \multirow{2}{*}{$\begin{array}{l}\text { Dev. } \\
\text { stage }\end{array}$} & \multicolumn{3}{|c|}{ Equation and parameter values } \\
\hline & C. finmarchicus ${ }^{\mathrm{a}}$ & P. elongatus ${ }^{\mathrm{b}}$ & O. similis ${ }^{\mathrm{C}}$ \\
\hline & $D=a(T+9.11)^{-2.05}$ & $=a(T+11.45)^{-2}$ & $D=a(T+5)^{-2.05}$ \\
\hline Egg & 595 & 1845 & 1430 \\
\hline N1 & 387 & 494 & 523 \\
\hline N2 & 582 & 825 & 929 \\
\hline N3 & 1387 & 2087 & 929 \\
\hline N4 & 759 & 1781 & 604 \\
\hline N5 & 716 & 1303 & 697 \\
\hline N6 & 841 & 1370 & 1022 \\
\hline $\mathrm{C} 1$ & 966 & 2055 & 604 \\
\hline $\mathrm{C} 2$ & 1137 & 2151 & 743 \\
\hline C3 & 1428 & 1701 & 790 \\
\hline $\mathrm{C} 4$ & 2166 & 1542 & 836 \\
\hline C5 & 4083 & 2776 & 790 \\
\hline \multicolumn{4}{|c|}{$\begin{array}{l}\text { aSource: Campbell et al. (2001) } \\
\text { bSources: McLaren et al. (1989), Thompson (1982), Landry (1983) }\end{array}$} \\
\hline
\end{tabular}


mally structured water column. Where DVM was detected, we have assumed that darkness was spent entirely in one depth habitat and daylight in another. The temperature function (Eq. 1) then translates into a 2-habitat function:

$$
D=x_{\mathrm{d}} \mathrm{a}\left(T_{\mathrm{d}}-\alpha\right)^{-b}+\left(1-x_{\mathrm{d}}\right) a\left(T_{\mathrm{n}}-\alpha\right)^{-b}
$$

where $x_{d}$ and $\left(1-x_{d}\right)$ is the proportion of a $24 \mathrm{~h}$ period spent in the daytime habitat or nighttime habitat, respectively, and $T_{\mathrm{d}}$ and $T_{\mathrm{n}}$ are the ambient temperatures experienced when in the day or nighttime habitats, respectively. Daylength varied according to Skartveit \& Olseth (1988).

We used chl a concentrations as a crude estimate of food availability. Although other food sources than algae are known to be used by particle-feeding copepods, no data from the FLEX study exist on other potential food types. Mapping chl a depth distribution at the central FLEX station with depth distributions of the copepod developmental stages suggested periods of potential food limitation. We used a value of $1.3 \mathrm{mg}$ chl $a \mathrm{l}^{-1}$ as an indication of when developmental rates become food independent. This translates roughly to the critical concentration (75 $\mu \mathrm{g} \mathrm{C} \mathrm{l}^{-1}$ ) for development of Calanus finmarchicus nauplii and copepodids (Campbell et al. 2001) and, similarly, to the food concentration (1 ppm) below which most stages of C. pacificus develop more slowly (Vidal 1980; assuming a mg $\mathrm{C}$ to ppm factor of 65, and a C:chl a ratio of 50; Jørgensen 1979). To assess the possible effect of food-restricted developmental rates or other physiological effects that prolong development during specific time periods, we analyzed the sensitivity of the estimated mortality rates to increases in stage duration of 50 to $100 \%$ as reported for C. finmarchicus by Campbell et al. (2001). We appreciate that there may be interspecific differences in the influences of food concentration and food type on developmental rates, but do not have field data available to address this issue.

\section{RESULTS}

The concentration of chl a increased immediately after thermal stratification of the water column, which began on approximately 20 April (Fig. 1). The peak spring bloom lasted from ca. 27 April to 6 May, with chl a levels above $6 \mathrm{mg} \mathrm{l}^{-1}$ in the upper $45 \mathrm{~m}$ of the water column. On 17 May the water column was mixed as a storm passed the station and this lead to a drop in chl a concentrations. From the distribution of chl a (Fig. 1) we consider the time periods prior to 20 April, between 13 and 18 May, and after 28 May as periods of potential food-limited growth for herbivorous zooplankton.

Calanus finmarchicus abundance was low and generally dominated by older developmental stages prior to the onset of spring bloom; however, substantial numbers of nauplii appeared approximately a week before the bloom (Fig. 2A). Population size increased appreciably after the rapid accumulation of chl $a$ in the water column.

Pseudocalanus elongatus was present in the water column at higher abundance than $C$. finmarchicus prior to the bloom and all developmental stages were present throughout the study period (Fig. 2B). Oithona similis was present at higher numbers than the other species, both before and after the onset of the bloom, and all developmental stages were continuously present (Fig. 2C). No numerical response was evident until 15 to $20 \mathrm{~d}$ after the onset of spring bloom, unlike the more immediate responses of both $C$. finmarchicus and $P$. elongatus. Based on abundances and variability of the developmental stages of the 3 species investigated, and avoiding time periods of storm-associated flushing, the time window from 18 April to 16 May was chosen for estimates of mortality.

Concerning vertical distributions, early copepodid stages ( $\mathrm{C} 1$ to $\mathrm{C} 4$ ) of Calanus finmarchicus were found in the upper $25 \mathrm{~m}$ during the night, but somewhat deeper (between 25 and $50 \mathrm{~m}$ ) by day. Older stages (C5s and adult females) were found deeper than $50 \mathrm{~m}$

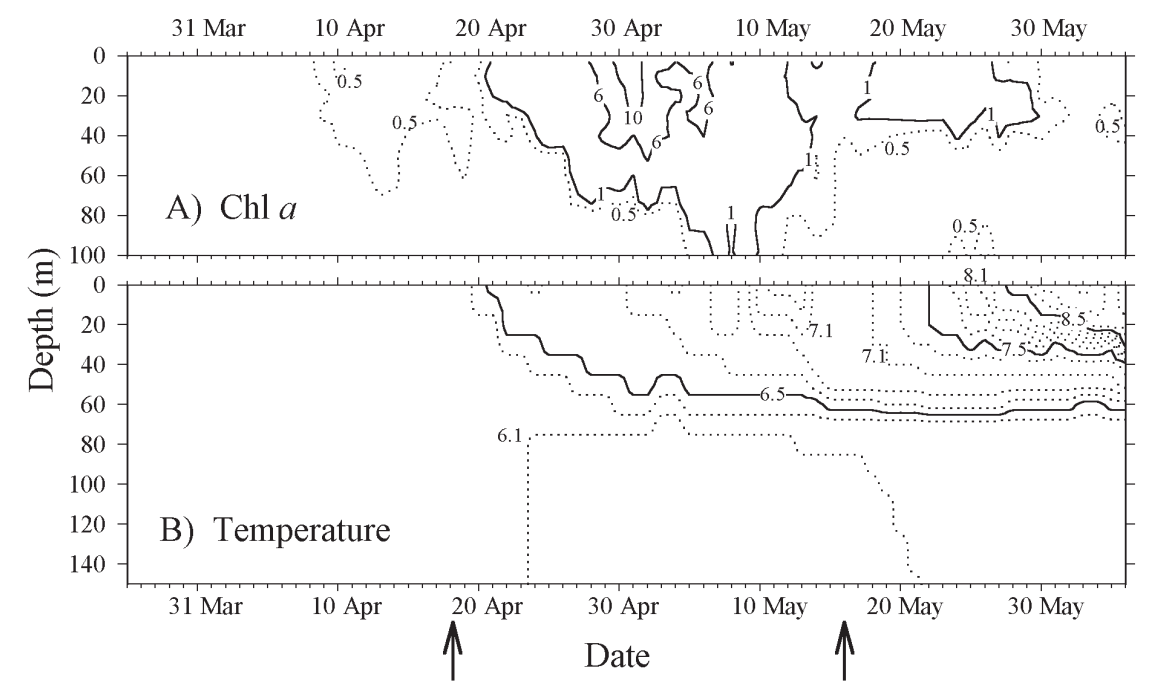

Fig. 1. Temporal variation in chl $a$ and temperature between 26 March and 5 June (Days 85 to 156 of year) at the Fladen Ground Experiment central station. Redrawn from Krause \& Radach (1989). (A) chl a $\left(\mathrm{mg} \mathrm{m}^{-3}\right)$; contour interval equals 0.5 below

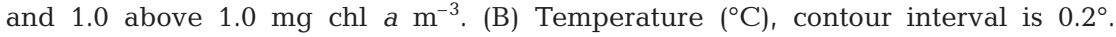
Arrows indicate the time interval over which mortality estimates were made 

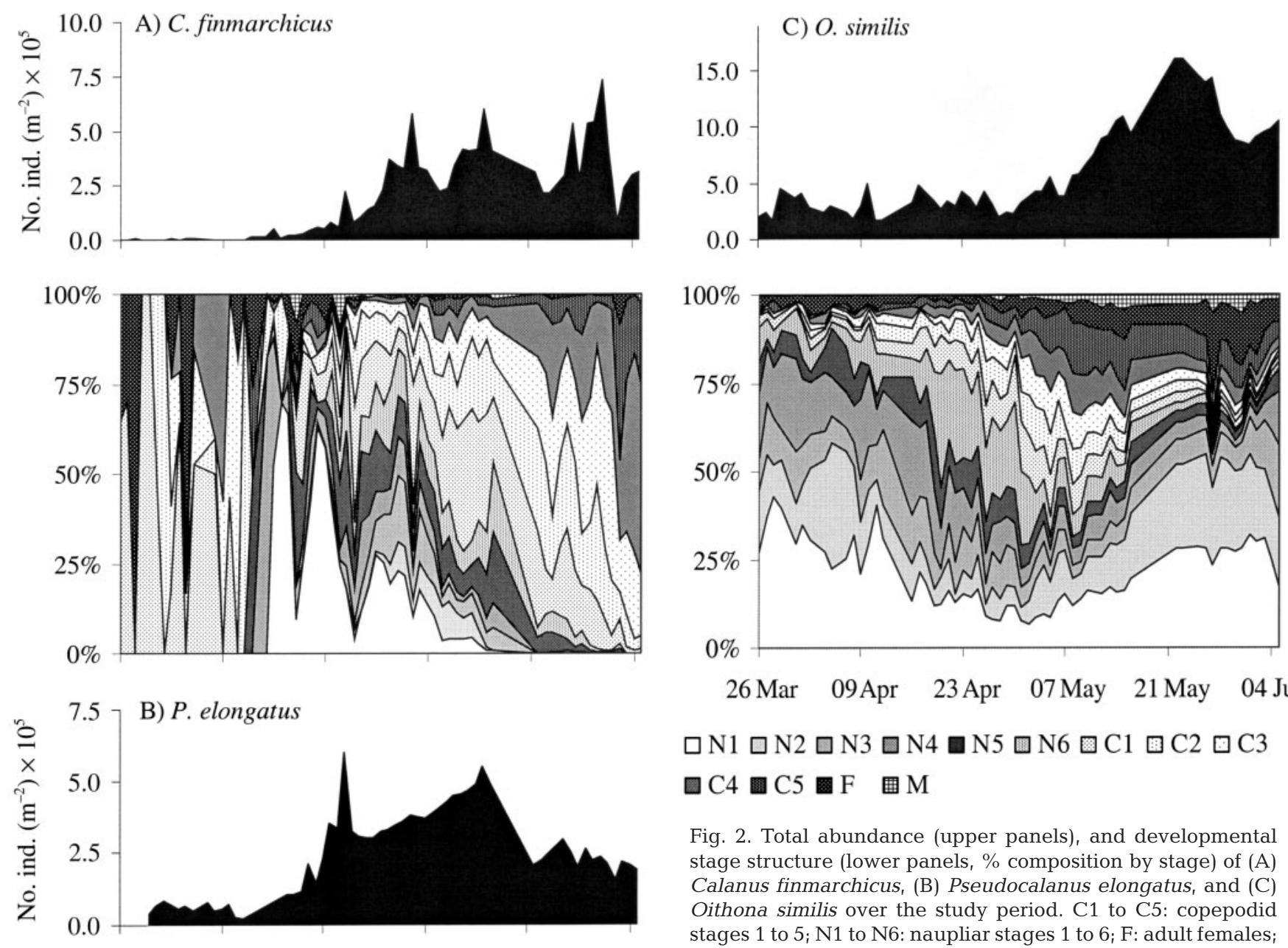

\section{Mar 09Apr 23Apr 07May 21 May 04 Jun \\ $\square \mathrm{N} 1 \square \mathrm{N} 2 \square \mathrm{N} 3 \square \mathrm{N} 4 \square \mathrm{N} 5 \square \mathrm{N} 6 \square \mathrm{C} 1 \square \mathrm{C} 2 \square \mathrm{C} 3$ 口4 回 5 圆 $\mathrm{F}$ 䧃 $\mathrm{M}$}

Fig. 2. Total abundance (upper panels), and developmental stage structure (lower panels, \% composition by stage) of (A) Calanus finmarchicus, (B) Pseudocalanus elongatus, and (C) Oithona similis over the study period. C1 to C5: copepodid stages 1 to 5 ; N1 to N6: naupliar stages 1 to 6 ; F: adult females: M: adult males

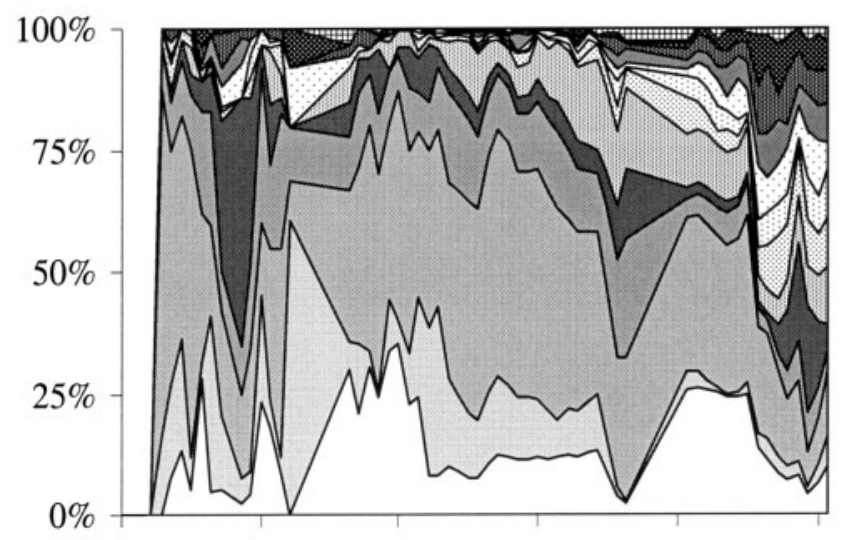

26Mar 09Apr 23Apr 07 May 21 May 04 Jun

both day and night (Fig. 3). Copepodid stages C1 to C3 of Pseudocalanus elongatus were found at the same depth (ca. $50 \mathrm{~m}$ ) both day and night, but a tendency to differentiate distributions on a diel scale was evident in the older stages, where day and nighttime distributions were at ca. 75 and $40 \mathrm{~m}$, respectively (Fig. 3). Oithona similis maintained the same depth distribution

both day and night (median depth $=30 \mathrm{~m}$ ) throughout the copepodid and adult stages (Fig. 3).

Instantaneous mortality rates were high in the first nauplii stages (N1 and N2) relative to other developmental stages in all species. In Calanus finmarchicus, mortality remained very low from N3 until peaking at C5, after which it again decreased for adult females (Fig. 4A). Mortality of Pseudocalanus elongatus was high early in life $\left(0.11 \mathrm{~d}^{-1}\right)$, dropped to intermediate levels $\left(<0.03 \mathrm{~d}^{-1}\right)$ for developmental stage N3 through N5, then increased towards $0.10 \mathrm{~d}^{-1}$ for $\mathrm{C} 1$, after which point it was low through $\mathrm{C} 4$ (ca. $0.00 \mathrm{~d}^{-1}$ ), and finally peaked for $\mathrm{C} 5\left(0.05 \mathrm{~d}^{-1}\right)$ (Fig. 4B). We have reservations about the unusually high mortality rate of $\mathrm{C} 1$ Pseudocalanus, which are discussed in more detail below. Mortality rates were not obtained for adult females because of the failure of the model to converge. Oithona similis only showed significant mortality at the first 2 nauplii stages ( 0.07 to $\left.0.03 \mathrm{~d}^{-1}\right)$, after which point mortality never reached higher values than $0.001 \mathrm{~d}^{-1}$ for the remainder of the life history (Fig. 4C). 

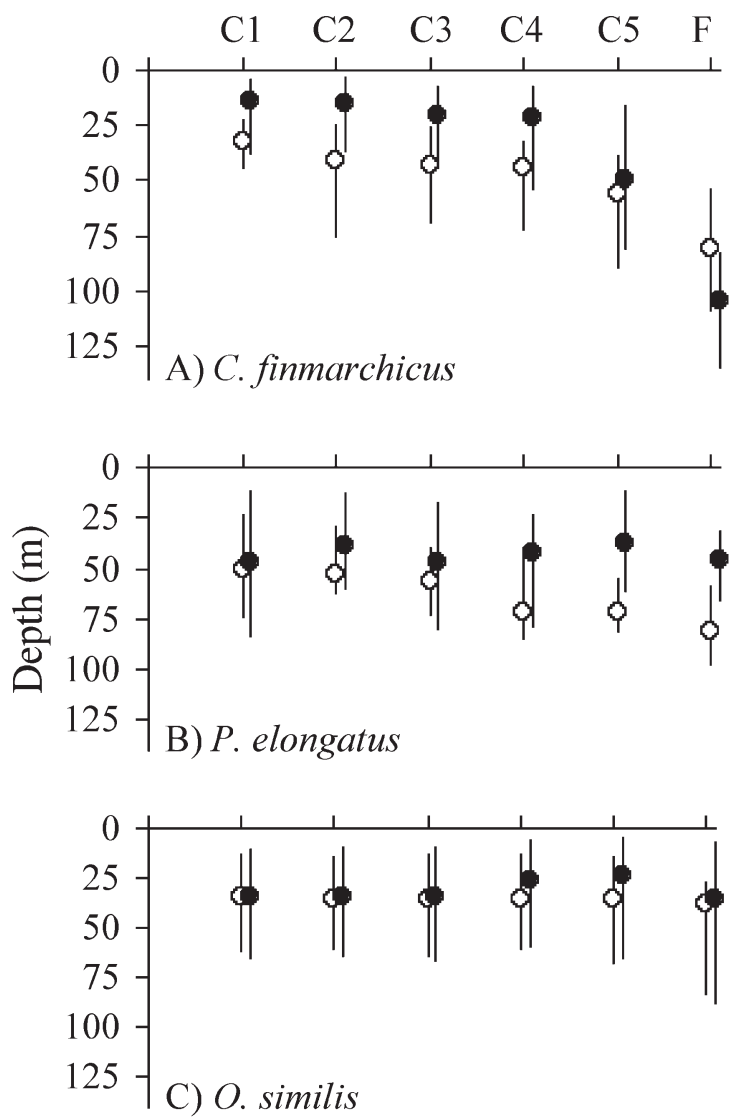

Fig. 3. Average day and night vertical distribution of the copepodid stages (C1 to C5) and adult females (F) of Calanus finmarchicus, Pseudocalanus elongatus, and Oithona similis from 11 May to 6 June. Closed and open circles denote median depth of distribution at night and day, respectively. Bars denote the depth interval containing $80 \%$ of the population. Number of vertical profiles used for night (day) points are: C. finmarchicus 19 (20); P. elongatus 18 (18); O. similis 18 (20)

We considered the effects of making different assumptions about the vertical distribution of the copepods on the temperatures (and hence development times) they experienced. The mortality rates in Fig. 4 are based on the assumption that individuals developed at the temperature corresponding to the weighted mean depth of the population. In Table 3 we show the deviations from these rates if most individuals instead develop at temperatures which occur at the depth occupied by the upper 80th and lower 20th percentiles of the each developmental stage. For the 3 species there were minor deviations from the mortality estimates obtained from the weighted mean depth of each population (Table 3). We also considered the possible effects of increased development times on mortality rate estimates, whether due to food limitation or other physiological effects that prolong development. A $50 \%$ increment in developmental time produced significantly higher mortality rates than presented in Fig. 4 for stage N3 Calanus finmarchicus and N3 Oithona similis. A $100 \%$ increment in developmental time produced significantly different mortality rates in $C$. finmarchicus N3, and $O$. similis N3 and N5 (Table 4).

\section{DISCUSSION}

\section{Mortality patterns}

On Fladen Ground in the northern North Sea during spring, 3 co-occurring copepod species showed some similarities in mortality patterns, but substantially different rates of mortality. All 3 copepod species experienced highest mortality rates in early life, followed by low mortality rates until the late copepodid stages. (Pseudocalanus elongatus at C1 may be an exception, as discussed below.) However, the magnitudes of the rates differed appreciably among taxa. The earliest naupliar stages of Calanus finmarchicus experienced mortality rates between 3 and 10 times higher than those of $P$. elongatus and Oithona similis at a corresponding developmental stage. Expressed as a function of body size, the scaling of these rates is in the
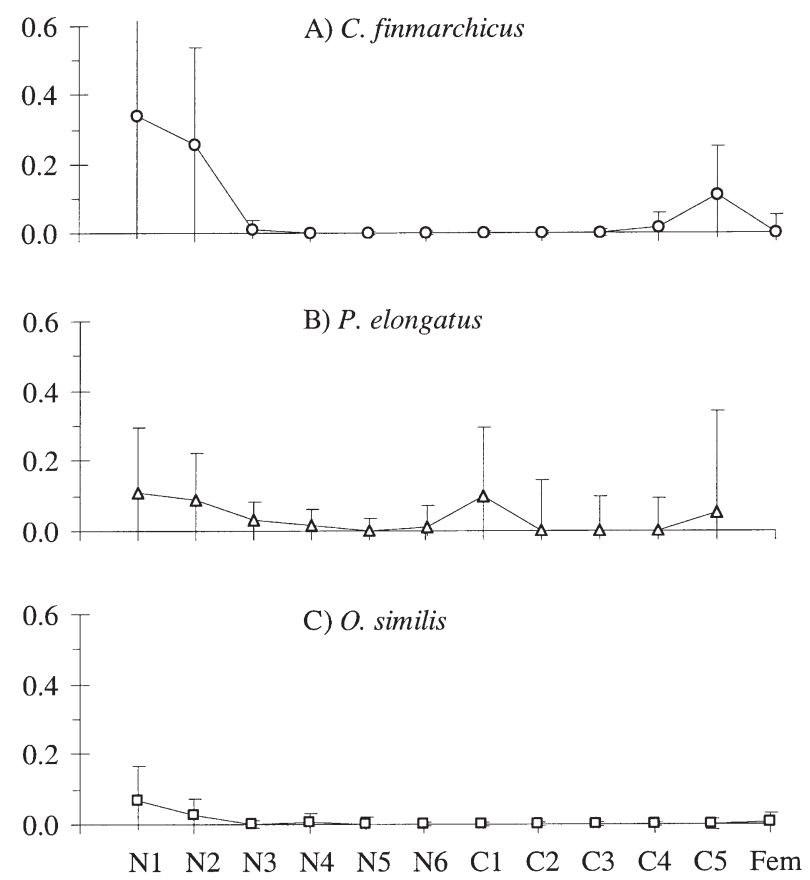

Fig. 4. Estimated instantaneous mortality rates for (A) Calanus finmarchicus, (B) Pseudocalanus elongatus, and (C) Oithona similis. C1 mortality rates for $P$. elongatus are uncertain, for reasons described in the text. N1 to N6: naupliar stages 1 to 6 ; C1 to C5: copepodid stages 1 to 5; Fem: female. Error bars denote $95 \%$ confidence limits 
Table 3. Deviation from standard mortality estimates $\left(\mathrm{d}^{-1}\right)$ at the weighted mean depth of the population due to differences in temperature at the upper 80th percentile and lower 20th percentile of each developmental (Dev.) stage population for the 3 copepod species. - : missing estimate due to failure of convergence in model. See 'Results' for details

\begin{tabular}{|lrrrrrr|}
\hline \multirow{2}{*}{$\begin{array}{l}\text { Dev. } \\
\text { stage }\end{array}$} & \multicolumn{2}{c}{ C. finmarchicus } & \multicolumn{2}{c}{ P. elongatus } & \multicolumn{2}{c|}{ O. similis } \\
& Lower & Upper & Lower & Upper & Lower & Upper \\
\hline N1 & -0.002 & 0.006 & -0.001 & 0.001 & 0.027 & 0.025 \\
N2 & 0.007 & -0.001 & -0.006 & -0.006 & -0.008 & -0.008 \\
N3 & 0.008 & 0.008 & 0.001 & 0.000 & -0.002 & -0.003 \\
N4 & 0.000 & -0.001 & 0.001 & 0.003 & 0.008 & 0.007 \\
N5 & 0.000 & 0.000 & 0.000 & 0.000 & 0.001 & 0.000 \\
N6 & 0.000 & 0.000 & 0.009 & 0.011 & 0.000 & 0.000 \\
C1 & 0.000 & 0.000 & 0.020 & 0.011 & 0.000 & 0.000 \\
C2 & 0.000 & 0.000 & 0.034 & 0.004 & 0.000 & 0.000 \\
C3 & 0.000 & 0.003 & 0.000 & 0.000 & 0.000 & 0.000 \\
C4 & 0.000 & 0.010 & 0.000 & 0.000 & 0.000 & 0.000 \\
C5 & 0.009 & 0.000 & 0.016 & -0.002 & -0.001 & -0.002 \\
Adult female & 0.007 & 0.00 & - & - & 0.000 & 0.000 \\
\hline
\end{tabular}

Table 4. Deviation from mortality estimates $\left(\mathrm{d}^{-1}\right)$ if developmental (Dev.) stage durations are increased by 50 and $100 \%$. Values in bold denote significant differences (at the $95 \%$ level) from estimates obtained in Fig. 4. See 'Results' for details

\begin{tabular}{|lrrrrrr|}
\hline \multirow{2}{*}{$\begin{array}{l}\text { Dev. } \\
\text { stage }\end{array}$} & \multicolumn{2}{c}{ C. finmarchicus } & \multicolumn{2}{c}{ P. elongatus } & \multicolumn{2}{c|}{ O. similis } \\
& $+50 \%$ & $+100 \%$ & $+50 \%$ & $+100 \%$ & $+50 \%$ & $+100 \%$ \\
\hline N1 & -0.023 & -0.080 & 0.032 & 0.032 & -0.020 & -0.065 \\
N2 & 0.064 & 0.029 & 0.061 & 0.073 & -0.015 & -0.020 \\
N3 & $\mathbf{0 . 0 5 0}$ & $\mathbf{0 . 1 1 9}$ & 0.014 & 0.022 & $\mathbf{0 . 0 1 4}$ & $\mathbf{0 . 0 1 4}$ \\
N4 & 0.000 & 0.000 & -0.018 & -0.015 & 0.015 & 0.015 \\
N5 & 0.000 & 0.000 & -0.017 & -0.014 & 0.015 & $\mathbf{0 . 0 2 6}$ \\
N6 & 0.000 & 0.000 & -0.038 & -0.032 & 0.001 & 0.001 \\
C1 & 0.000 & 0.000 & -0.043 & -0.048 & 0.000 & 0.000 \\
C2 & 0.000 & 0.000 & -0.013 & -0.008 & 0.000 & 0.000 \\
C3 & 0.000 & 0.000 & 0.005 & 0.029 & 0.000 & 0.000 \\
C4 & -0.015 & -0.015 & 0.000 & 0.027 & 0.000 & 0.000 \\
C5 & -0.044 & -0.044 & -0.056 & -0.072 & -0.004 & -0.005 \\
Adult female & 0.000 & 0.000 & - & - & 0.000 & 0.000 \\
\hline
\end{tabular}

opposite direction of predictions by allometric arguments, pointing to the need to understand the biological basis of such interspecific differences.

As the vertical distributions of the nauplii are not available from the FLEX study, we cannot address interspecific differences in vertical position and the extent of overlap with potential predators. In the Georges Bank region in the NW Atlantic, nauplii of Calanus finmarchicus and Pseudocalanus newmani + moultoni overlap extensively in the vertical plane and show similar body sizes (Ohman et al. 2002). The chief difference between Calanus and Pseudocalanus is in their behavior, as reflected in the study of Sell et al. (2001). Their results showed that the omnivorous copepod Metridia lucens captures Calanus nauplii at rates 3 to 7 times higher than Pseudocalanus nauplii. The Pseudocalanus nauplii appear to have much better escape responses than Calanus nauplii of the same size. The very low mortality rates of Oithona nauplii are related to their more quiescent behavior (in Titelman \& Kiørboe 2003). Mortality rates of copepod nauplii will be affected by encounter rates with predators, which are influenced by relative swimming speeds (Gerritsen \& Strickler 1977), but modulated by naupliar escape behavior (Landry 1980, Greene 1986).

The initial stage-specific decline in mortality rates observed for the 3 species is likely due to increased body size, faster swimming speed, and therefore increased escape responses with successive naupliar stages. The stage-specific decline in mortality rate is similar to that observed for Calanus spp. in Lurefjorden, a fjord dominated by invertebrate predators (Eiane et al. 2002), as well as in the open Norwegian Sea at Ocean Station M (Ohman et al. 2004). It differs from the patterns for Calanus spp. in Sørfjorden, a fjord dominated by vertebrate planktivores (Eiane et al. 2002), and Georges Bank in the Northwest Atlantic (Ohman et al. 2002). Calanus spp. in the latter 2 systems experience considerably higher mortality at intermediate developmental stages. Such differences among regions are likely due to sitespecific differences in predator communities. Our estimate of Pseudocalanus elongatus mortality rate is somewhat lower (between 30 and $50 \%$ of average mortality from N1 through C5) than that of Pseudocalanus newmani in Dabob Bay (Ohman \& Wood 1995) and P. newmani + moultoni on Georges Bank (Ohman et al. 2002). The differences arise as the 2 latter populations suffer appreciably higher mortality rates from developmental stages N4 through N6, and from C2 through C4, than the North Sea population. The retentive circulation in both Dabob Bay and Georges Bank may serve to concentrate predators on mid-life-history stages of Pseudocalanus spp. at more elevated abundances than in the North Sea. The marked peak in mortality of developmental stage C1 of $P$. elongatus in the present study is comparable to the elevated mortality rates experienced by C1s in Dabob Bay (Ohman \& Wood 1995). Therefore it is possible that this is a characteristic trait in Pseudocalanus spp. dynamics. However, the peaked pattern observed here is quite 
different from the relative constancy of mortality rates observed on Georges Bank (Ohman et al. 2002). If abundances of C1 P. elongatus were underestimated for some reason in the present study, or stage durations were in error, this could result in an overestimate of mortality during that period of the life cycle.

We know of no other field estimates of mortality patterns in Oithona similis, but note that mortality is low compared to the other species, and remains low throughout development (Fig. 4). Since Oithona spp. females carry their eggs, egg mortality rates can also be inferred to be low, as observed for adult females (barring declines in physiological viability of eggs). The remarkable implication of the $O$. similis mortality schedule is that virtually all individuals that survive to the end of the N2 stage will also survive to be adult females in the natural ocean environment.

\section{Diel vertical migration}

Vertical migration out of food rich and warm surface waters in the day time increases fitness when visually searching predators constitute an important threat (Ohman et al. 1983, Aksnes \& Giske 1990, Ohman 1990), but comes at a cost of prolonged developmental times, or reduced fecundity, due to reduced foraging rates and lower temperatures (Aksnes \& Giske 1990). During the study period, diel vertical migrations (DVM) were a prominent feature of later copepodid stages of Pseudocalanus elongatus and earlier copepodid stages of Calanus finmarchicus (Figs. 3 \& 5). The shallow depth distribution of $C$. finmarchicus $\mathrm{C} 1$ to $\mathrm{C} 4$ at night overlapped the zone of highest chl a concentration, while daytime depth was in low $\left(<0.5 \mathrm{mg} \mathrm{chl} \mathrm{a} \mathrm{m}^{-3}\right)$ concentrations, indicating a predominantly nocturnal feeding pattern. Daro (1980) found grazing rates of C. finmarchicus to peak at ca. $400\left(\mathrm{mg} \mathrm{C} \mathrm{m}^{-2} \mathrm{~h}^{-1}\right)$ at nighttime, but to fall to $<10\left(\mathrm{mg} \mathrm{C} \mathrm{m}^{-2} \mathrm{~h}^{-1}\right)$ around noon in the upper $40 \mathrm{~m}$ in late May and early June at the central station. Migrating $P$. elongatus (C4 to adult females) stay at deeper depths by day, but we have no information about grazing periodicity in this species. We note that lower temperatures at their daytime depth imply an increase in development time of ca. 10\%.

Predation risk in the plankton is size-selective (Brooks \& Dodson 1965), and anti-predation behaviors therefore should co-vary with size (Bollens \& Frost 1989, Lampert 1993). Predictions of size-differentiated migration behavior have been made (Iwasa 1982, Fiksen \& Giske 1995, DeRobertis 2002), and observations exist for field populations (Andersen \& Sardou 1994, De Robertis et al. 2000). In general, in the present study, the smaller copepodids showed little dayto-night variation in depth distribution, while larger

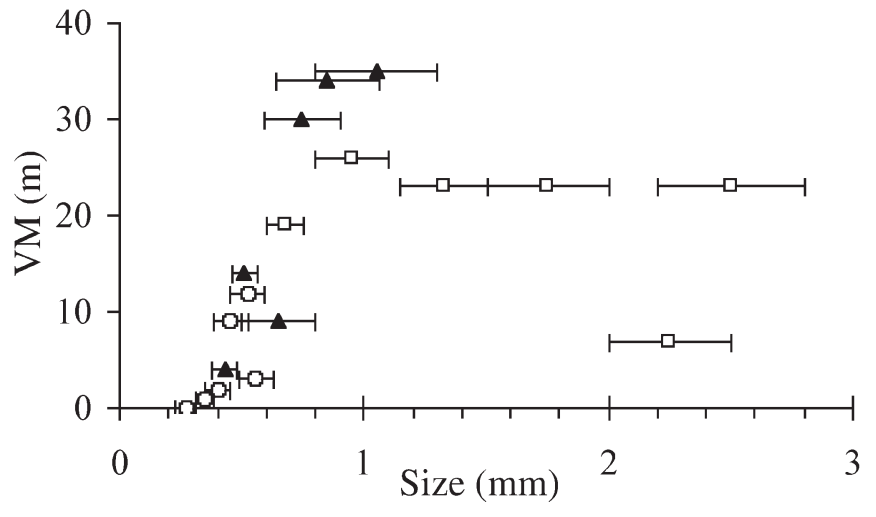

Fig. 5. Relationship between amplitude of diel vertical migration (VM) and body size (as prosome length) for copepodid stages of Oithona similis (O), Pseudocalanus elongatus ( $(\mathbf{\Lambda})$, and Calanus finmarchicus (ם) during 11 May to 6 June 1976. Horizontal bars denote the approximate size range of each developmental stage

forms tended to show larger amplitude migrations (Fig. 5). Calanus finmarchicus $\mathrm{C} 5 \mathrm{~s}$ and adult females deviate from this pattern by staying deeper in the water column both day and night, perhaps to compensate increased predation risk associated with larger body size. Adult female $C$. finmarchicus reside deeper in the water column than C5s, and this deeper habitat is associated with reduced rates of mortality.

Oithona similis did not show DVM during the study period, and the low mortality rates in this species appear to be related to other characteristics of its behavior and morphology. This copepod is small and rather transparent, and therefore may be the least conspicuous to visual planktivores (Aksnes \& Giske 1990). Furthermore, as Oithona spp. tend to drift passively, encounter rates with mechanosensory planktivores can be assumed to be lower than for faster-moving species (Gerritsen \& Strickler 1977, Kiørboe \& Visser 1999). Nauplii of Oithona spp. swim more slowly than nauplii of Calanus spp. or Pseudocalanus spp. (summarized in Titelman \& Kiørboe 2003). O. similis is also a particulate feeder that does not generate feeding currents, thus its hydromechanical signature is likely to be very limited relative to active suspension-feeding copepods (Paffenhöfer 1993, Kiørboe \& Visser 1999). The ubiquitous distribution, and often high abundances, of Oithona spp., despite relatively low rates of feeding, respiration, and growth, may be attributed to their surprisingly low rates of mortality.

\section{Life-history strategies}

Generation times (as egg through C5, Table 2) are similar for Calanus finmarchicus and Pseudocalanus 
elongatus, but significantly longer (ca. 26\%) for Oithona similis at the same temperature. Taking into account both development times and stage-specific mortality rates, average cohort survival from the start of developmental stage N1 to the end of C5 is 4.3, 10.3, and $44.0 \%$ in $C$. finmarchicus, $P$. elongatus, and $O$. similis, respectively. Provided these differences reflect true values for the whole life cycle, including eggs, balanced population dynamics require fecundity to be substantially higher in C. finmarchicus than in O. similis and P. elongatus (Dam \& Tang 2001, Hirst \& Kiørboe 2002). Egg production rates for $C$. finmarchicus typically fall within the range of 10 to 70 eggs female ${ }^{-1} \mathrm{~d}^{-1}$ (Hirche 1990, Ohman \& Runge 1994), while those for $O$. similis and Pseudocalanus spp. span 1.5 to 4.5 eggs female ${ }^{-1} \mathrm{~d}^{-1}$ (Eaton 1971, Sabatini \& Kiørboe 1994), and 0.5 to 5.5 eggs female ${ }^{-1} \mathrm{~d}^{-1}$ (Paffenhöfer \& Harris 1976, Frost 1985, Jonasdottir 1989), respectively.

Mortality did not scale with size of copepods (linear and logarithmic regressions of mortality versus size of all nauplii, all copepodids, and all developmental stages combined consistently resulted in $\mathrm{r}^{2}$ values < 0.09). Thus, the interspecific patterns we observe are at variance with the view that mortality should scale inversely with adult body size (Peterson \& Wroblewski 1984). Furthermore, N1 and N2 mortality rates, the stages of peak instantaneous mortality for all 3 species, also vary positively with naupliar body size (Fig. 6), and not negatively, as predicted from allometric arguments (Hirst \& Kiørboe 2002). As noted above, the interspecific differences in naupliar mortality are related to the quiescent swimming of Oithona spp., rapid escape responses of PseudoCalanus spp., and slower swimming of Calanus spp. nauplii.

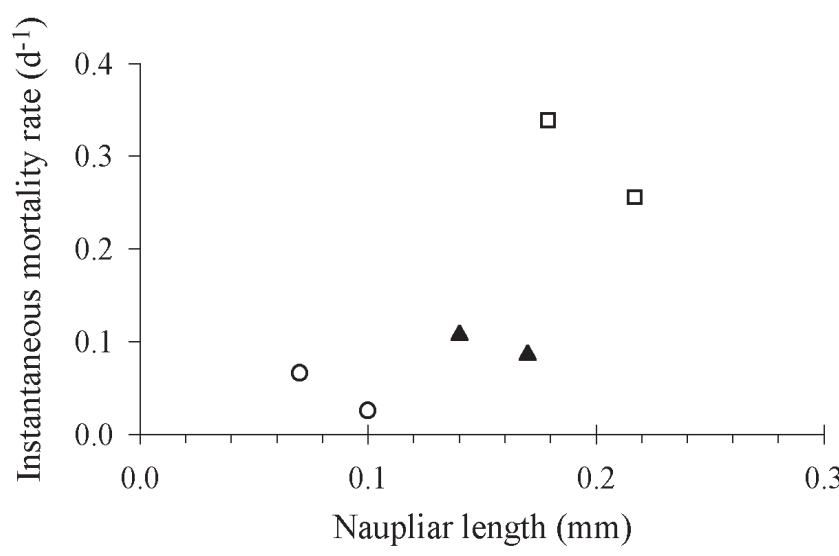

Fig. 6. Relationship between instantaneous mortality rate and total length for nauplius stages 1 and 2 of Oithona similis (O),

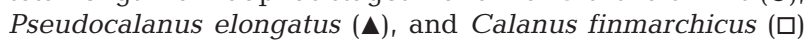

\section{CONCLUSIONS}

Differences among Calanus finmarchicus, Pseudocalanus elongatus and Oithona similis in mortality, together with life-history and behavioral contrasts (Table 1, Fig. 3) shed light on key adaptations to life in the pelagial. The smallest species, $O$. similis, is a particulate feeder that primarily drifts passively, without generating a feeding current. Therefore, although lacking vertical migration behavior, it is relatively inconspicuous to both tactile and visual predators and experiences low mortality throughout its life span. This strategy is not likely to be very efficient for food collection; thus, low mortality comes at a cost of reduced growth and fecundity compared to that of herbivorous copepods. $P$. elongatus is capable of faster growth and perhaps higher fecundity than $O$. similis. Its larger size and feeding current probably makes it more conspicuous to visual and tactile planktivores, but rapid escape responses by nauplii and DVM by later developmental stages (Fig. 5) may, to some degree, compensate. Of the copepods studied, based on size alone $C$. finmarchicus is probably the most visually conspicuous to the predator community. It engages in DVM from developmental stage $\mathrm{C} 1$ (when it is approximately the same size as the migrating $P$. elongatus), and then remains deeper in the water column after stage C5. This could reflect ontogenetic migration out of surface waters associated with dormancy (Conover 1988), thus minimizing time spent in the surface zone when visual predators are effective (Kaartvedt 2000).

Our results, together with previously published work on mortality patterns of copepods, indicate that mortality varies by taxon co-occurring in the same environment, as well as by geographic region. This variability is probably an effect of local differences in the environment, such as predation pressure, but also in the organisms' life-history strategies and behavior.

Acknowledgements. We thank M. Krause and the late J. Trahms for generously sharing data from FLEX 1976, and express particular appreciation to D. Aksnes for his insights and S. Kaartvedt for comments on a previous draft. Four anonymous reviewers provided constructive comments on the manuscript. K.E. was supported by a grant from the Research Council of Norway. This is contribution number 419 of the US GLOBEC program, supported by NSF and NOAA through NSF OCE01-10300, and a contribution of the Pelagic Invertebrates Collection of SIO.

\section{LITERATURE CITED}

Aksnes DL, Giske J (1990) Habitat profitability in pelagic environments. Mar Ecol Prog Ser 64:209-215

Aksnes DL, Ohman MD (1996) A vertical life table approach to zooplankton mortality estimation. Limnol Oceanogr 41: 1461-1469 
Andersen V, Sardou J (1994) Pyrosoma atlanticum (Tunicata, Thaliacea) - Diel migration and vertical distribution as a function of colony size. J Plankton Res 16:337-349

Bollens SM, Frost BW (1989) Predator induced diel vertical migration in a marine planktonic copepod. J Plankton Res 11:1047-1065

Brooks JL, Dodson SI (1965) Predation, body size, and composition of plankton. Science 150:28-35

Campbell RG, Wagner MM, Teegarden GJ, Boudreau CA, Durbin EG (2001) Growth and development rates of the copepod Calanus finmarchicus reared in the laboratory. Mar Ecol Prog Ser 221:161-183

Carlotti F, Radach G (1996) Seasonal dynamics of phytoplankton and Calanus finmarchicus in the North Sea as revealed by a coupled one-dimensional model. Limnol Oceanogr 41:522-539

Carlotti F, Giske J, Werner F (2000) Modeling zooplankton dynamics. In: Harris RP, Wiebe PH, Lenz J, Skjoldal HR, Huntley M (eds) Zooplankton methodology manual. Academic Press, San Diego, p 571-667

Conover RJ (1988) Comparative life histories in the genera Calanus and Neocalanus in high latitudes of the northern hemisphere. Hydrobiologia 167/168:127-142

Corkett CJ, McLaren IM (1978) The biology of Pseudocalanus. Adv Mar Biol 15:1-231

Corkett CJ, McLaren IA, Sévigny JM (1986) The rearing of the marine copepods Calanus finmarchicus (Gunnerus), C. glacialis (Jaschnov) and C. hyperboreus (Kroyer) with comment on the equiproportional rule. Proc 2nd Int Conf Copepoda, Ottawa, Canada, 13 to 17 Aug 1984. National Museums of Canada, Ottawa, p 539-546

Dam HG, Tang KW (2001) Affordable egg mortality: constraining copepod egg mortality with life history traits. J Plankton Res 23:633-640

Daro MH (1980) Field study of the diel feeding of a population of Calanus finmarchicus at the end of a phytoplankton bloom FLEX 7622 May-5 June. «Meteor» Forsch Ergeb 22:123-132

DeRobertis A (2002) Size-dependent visual predation risk and the timing of vertical migration: an optimization model. Limnol Oceanogr 47:925-933

DeRobertis A, Jaffe JS, Ohman MD (2000) Size-dependent visual predation risk and the timing of vertical migration in zooplankton. Limnol Oceanogr 45:1838-1844

Eaton JM (1971) Studies on the feeding and reproductive biology of the marine cyclopoid copepod, Oithona similis Claus. PhD thesis, Dalhousie University, Halifax

Eiane K, Aksnes DL, Giske J (1997) The significance of optical properties in competition among visual and tactile planktivores: a theoretical study. Ecol Model 98:123-136

Eiane K, Aksnes DL, Ohman MD, Wood S, Martinussen MB (2002) Stage-specific mortality of Calanus spp. under different predation regimes. Limnol Oceanogr 47:636-645

Fiksen Ø, J Giske (1995) Vertical distribution and population dynamics of copepods by dynamic optimization. ICES J Mar Sci 52:483-503

Fransz HG, van Arkel WG (1980) Zooplankton activity during and after the phytoplankton spring bloom at the central station in the FLEX box, northern North Sea, with special reference to the calanoid copepod Calanus finmarchicus (Gunn.). «Meteor» Forsch Ergeb 22:113-121

Frost BW (1985) Food limitation of planktonic marine copepods Calanus pacificus and Pseudocalanus sp. in a temperate fjord. Arch Hydrobiol 21:1-13

Gerritsen J, Strickler JR (1977) Encounter probabilities and community structure in zooplankton: a mathematical model. J Fish Res Board Can 34:73-82
Greene CH (1986) Patterns of prey selection: implications of predator foraging tactics. Am Nat 128:824-839

Hirche HJ (1990) Egg production of Calanus finmarchicus at low temperatures. Mar Biol 106:53-58

Hirst AG, Kiørboe T (2002) Mortality of marine planktonic copepods: global rates and patterns. Mar Ecol Prog Ser 230:195-209

Iwasa Y (1982) Vertical migration of zooplankton: a game between predator and prey. Am Nat 120:171-180

Jonasdottir SH (1989) Effects of food concentration on eggproduction rates of two species of Pseudocalanus: laboratory observations. J Exp Mar Biol Ecol 130:33-43

Jørgensen SE (1979) Handbook of environmental data and ecological parameters. International Society for Ecological Modelling, Pergamon Press, Oxford, p 10-11

Kaartvedt S (2000) Life history of Calanus finmarchicus in the Norwegian Sea in relation to planktivorous fish. ICES J Mar Sci 57:1819-1824

Kaartvedt S, Melle W, Knutsen T, Skjoldal HR (1996) Vertical distribution of fish and krill beneath water of varying optical properties. Mar Ecol Prog Ser 136:51-58

Kiørboe T, Sabatini M (1994) Reproductive and life cycle strategies in egg-carrying cyclopoid and free-spawning calanoid copepods. J Plankton Res 16:1353-1366

Kiørboe T, Visser AW (1999) Predator and prey perception in copepods due to hydromechanical signals. Mar Ecol Prog Ser 179:81-95

Krause M, Radach G (1980) On the succession of developmental stages of herbivorous zooplankton in the North Sea during FLEX 76. 1. First statement about the main groups of the zooplankton community. Forsch Ergeb 22:133-149

Krause M, Radach G (1989) On the relations of vertical distribution, diurnal migration and nutritional state of herbivorous zooplankton in the Northern North Sea during FLEX 1976. Int Rev Gesamten Hydrobiol 74:371-417

Krause M, Trahms J (1982) Vertical distribution of copepods (all developmental stages) and other zooplankton during spring bloom in the Fladen Ground area of the North Sea. Neth J Sea Res 16:217-230

Krause M, Trahms J (1983) Zooplankton dynamics during FLEX 76. In: Sundermann J, Lenz W (eds) North Sea dynamics. Springer-Verlag, Heidelberg, p 632-661

Lampert W (1993) Phenotypic plasticity of the size at 1st reproduction in daphnia - the importance of maternal size. Ecology 74:1455-1466

Landry MR (1980) Detection of prey by Calanus pacificus: implications of the first antennae. Limnol Oceanogr 25: $545-549$

Landry MR (1983) The development times of marine calanoid copepods with comment on the isochronal rule. Limnol Oceanogr 28:614-624

Lindley JA, Williams R (1980) Plankton of the Fladen Ground during FLEX 76 II. Population dynamics and production of Thysanoessa inermis (Crustacea: Euphausiacea). Mar Biol 57:79-86

McLaren IA, Sévigny JM, Corkett CJ (1989) Temperature development in Pseudocalanus species. Can J Zool 67: $559-564$

Ohman MD (1990) The demographic benefits of diel vertical migration by zooplankton. Ecol Monogr 60:257-281

Ohman MD, Hirche HJ (2001) Density-dependent mortality in an oceanic copepod population. Nature 412:638-641

Ohman MD, Runge JA (1994) Sustained fecundity when phytoplankton resources are in short supply: omnivory by Calanus finmarchicus in the Gulf of St. Lawrence. Limnol Oceanogr 39:21-36

Ohman MD, Wood SN (1995) The inevitability of mortality. 
ICES J Mar Sci 52:517-522

Ohman MD, Frost BW, Cohen EB (1983) Reverse diel vertical migration: an escape from invertebrate predators. Science 220:1404-1406

Ohman MD, Runge JA, Durbin EG, Field DB, Niehoff B (2002) On birth and death in the sea. Hydrobiologia 480:55-68

Ohman MD, Eiane K, Durbin EG, Runge JA, Hirche HJ (2004) A comparative study of Calanus finmarchicus mortality patterns in five localities in the North Atlantic. ICES J Mar Sci (in press)

Paffenhöfer GA (1993) On the ecology of marine cyclopoid copepods (Crustacea, Copepoda). J Plankton Res 15:37-55

Paffenhöfer GA, Harris R (1976) Feeding, growth and reproduction of the marine planktonic copepod Pseudocalanus elongatus Boeck. J Mar Biol Assoc UK 56:327-344

Peterson I, Wroblewski JS (1984) Mortality rates of fishes in the pelagic ecosystem. Can J Fish Aquat Sci 41:1117-1120

Rey C (2000) Etude du développement, de la croissance, de la ponte et de leurs sources de variabilité chez des copépodes marins elevés en milieu contrôlé. PhD thesis, Université Pierre et Marie Curie, Paris VI, p 1-168

Rosland R, Giske J (1994) A dynamic optimization model of the diel vertical distribution of a pelagic planktivorous fish. Prog Oceanogr 34:1-43

Sabatini M, Kiørboe T (1994) Egg production, growth and development of the cyclopoid copepod Oithona similis. J Plankton Res 16:1329-1351

Sell AF, Van Keuren D, Madin LP (2001) Predation by omnivorous copepods on early developmental stages of Calanus finmarchicus and Pseudocalanus spp. Limnol Oceanogr 46:953-959

Editorial responsibility: Otto Kinne (Editor),

Oldendorf/Luhe, Germany
Skartveit A, Olseth JA (1988) Varighetstabeller for belysning mot 5 flater på 16 norske stasjoner. Meteorological Report Series. 7, University of Bergen, Bergen, p 1-136 (in Norwegian)

Soetje KC, Huber K (1980) A compilation of data on the thermal stratification at the central station in the northern North Sea during FLEX 76. Forsch Ergeb 22:69-77

Solow AR, Steele JH (1995) Scales of plankton patchiness: biomass versus demography. J Plankton Res 17:1669-1677

Thompson BM (1982) Growth and development of Pseudocalanus elongatus and Calanus sp. in the laboratory. J Mar Biol Assoc UK 62:359-372

Titelman J, Kiørboe T (2003) Motility of copepod nauplii and implications for food encounter. Mar Ecol Prog Ser 247: 123-135

Verity PG, Smetacek V (1996) Organisms life cycles, predation, and the structure of marine pelagic ecosystems. Mar Ecol Prog Ser 130:277-293

Vidal J (1980) Physioecology of zooplankton. I. Effects of phytoplankton, temperature, and body size on the growth rate of Calanus pacificus and Pseudocalanus sp. Mar Biol 56:111-134

Williams R, Lindley JA (1980a) Plankton of the Fladen Ground during FLEX 76 I. Spring development of the plankton community. Mar Biol 57:73-78

Williams R, Lindley JA (1980b) Plankton of the Fladen Ground during FLEX 76 III. Vertical distribution, population dynamics and production of Calanus finmarchicus (Crustacea: Copepoda). Mar Biol 60:47-56

Wood SN (1994) Obtaining birth and mortality patterns from structured population trajectories. Ecol Monogr 64:23-44

Submitted: August 5, 2003; Accepted: November 18, 2003 Proofs received from author(s): February 16, 2004 